\title{
Effects of Omega-3 Co-Administered with Therapeutic Dose of lornoxicam on Male Rats' Liver
}

Israa A. Majeed"1, Nada N. Al-Shawi**

* Ministry of Health and Environment, Dyala Health Directorate, Dyala, Iraq.

** Department of Pharmacology and Toxicology, College of Pharmacy, University of Baghdad, Baghdad-Iraq.

\section{Abstract}

Lornoxicam drug is an enolic acid derivative (oxicam) of the non-steroidal anti-inflammatory drugs class. It is used to relieve pain and inflammation in rheumatic disease and osteoarthritis and other inflammation. Furthermore, such drug has side effects similar to other NSAIDs, most commonly gastrointestinal and headache. Severe but seldom adverse effects include bleeding, bronchospasms and the extremely rare Stevens-Johnson syndrome. Adverse effects on liver were not previously-investigated.

Omega-3 fatty acids are poly-unsaturated fatty-acids (including $\alpha$-linolenic acid, eicosapentaenoic acid and docosahexaenoic acid) have roles in human physiology. They possess anti-inflammatory effect, reduce blood pressure; in addition to other health effects.

The aim of this study is to investigate whether lornoxicam, omega 3 fatty acid, or co-administration of omega 3 with lornoxicam have adverse effects on liver of healthy male rats.

Twenty-eight adults male rats weighing 180-200g were used in this study and the animals were randomly divided into four groups of seven rats each. Group I: negative control/rats intraperitoneally injected with normal saline in a dose 5ml/kg/day; Group II: rats intraperitoneally injected with lornoxicam at dose $0.7 \mathrm{mg} / \mathrm{kg} / \mathrm{day}$; Group III: rats orally-administered omega-3 only at a dose $185 \mathrm{mg} / \mathrm{kg} / \mathrm{day}$; Group IV: rats co-administered omega-3 $(185 \mathrm{mg} / \mathrm{kg} /$ day $)$ orally and intra-peritoneal injection of lornoxicam $(0.7 \mathrm{mg} / \mathrm{kg} / \mathrm{day})$. Duration of treatment was 14-day; and at day 15 of the study, the liver of each rat was excised for the preparation of tissue-homogenate to be utilized for the estimation of ALT, AST, TNF-alpha and IL-10. Omega-3 can reduce signs of inflammation through the reduction- of TNF-alpha level and elevation of IL-10 with a significant reduction in ALT enzyme activity level in rats' liver tissue homogenate. In conclusion, Omega-3 poly-unsaturated fatty-acids may have a protective effect against hepatocytes inflammation when co-administered with lornoxicam.

Keywords: Lornoxicam, Omega 3, Liver enzymes, TNF-alpha, IL-10.

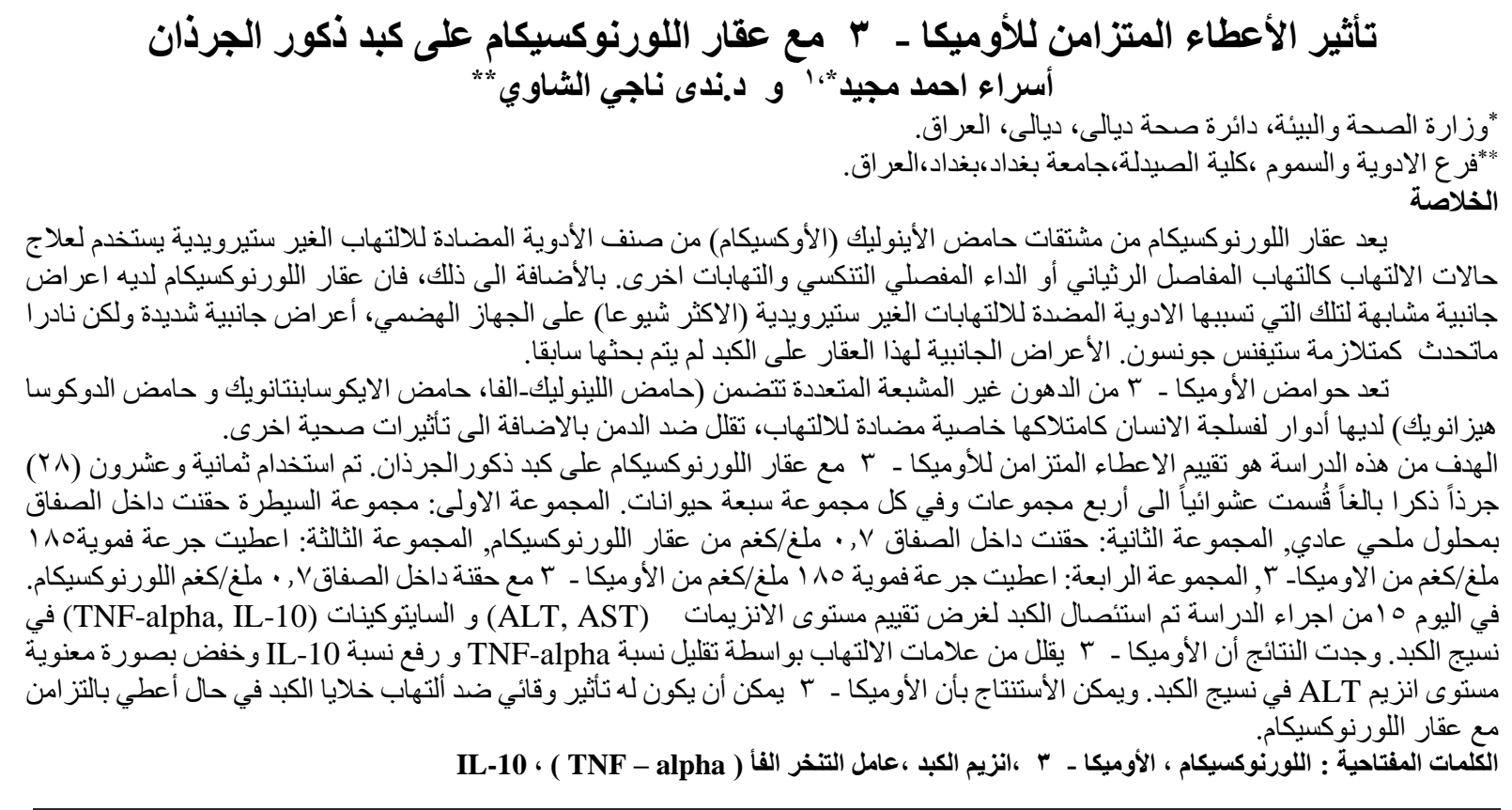

${ }^{1}$ Corresponding author: israa.ahmed10@yahoo.com

Received: 16/6/2019

Accepted: 21/8 /2019

Iraqi Journal of Pharmaceutical Sciences 


\section{Introduction}

The liver is the fundamental and major site of drugs-metabolism; and non-steroidal antiinflammatory drugs (NSAIDs) are the most widely utilized medications for pain-control and inflammation in several countries ${ }^{(1)}$. The main cause of the limitation for the use of such drugs class is the gastrointestinal (GI) adverse effects such as the bleeding ulcers and hepatic adverse effects ${ }^{(2)}$.

Lornoxicam is a potent NSAID with analgesic, antipyretic and anti-inflammatory effects that used to relieve the pain of postoperative in orthopaedic surgery (3) (4). Moreover, lornoxicam caused adverse effects during its hepatic metabolism (5).

Omega-3 poly-unsaturated fatty-acid (PUFAs) including docosahexaenoic acid (DHA) and eicosapentaenoic acid (EPA) is an essential oil for the development of fetal and health aging; it plays a role in anti-inflammatory process and cell membrane viscosity ${ }^{(6,7)}$. Furthermore, it has been reported that the intake of omega-3 PUFA may provide a protective impact against the most common adverse effects of NSAIDs such as cardiovascular and gastrointestinal ${ }^{(8)}$. The drugliver interaction and drug-drug interaction must also be considered. Authors reported that drug-drug interactions (DDIs) have been noticed when NSAIDs are co-administered with some common medications ${ }^{(9)}$; thus, the safety profile of NSAIDs alone, and in combination with other medications and supplements needs to be assessed in healthy status.

The aim of this study is to investigate whether lornoxicam, or omega 3 fatty acid, or coadministration of omega 3 with lornoxicam have adverse effects on liver of healthy male rats.

\section{Materials and Methods Animals}

Twenty eight (28) healthy adult Albino male rats, weighing 180-200gm were used in this study; they were obtained and maintained in the Animal House of the College of Pharmacy, University of Baghdad under conditions of controlled humidity and temperature and light-dark cycle. Animals were fed standard laboratory pellets and tap water ad libitum during the experiment duration. This study was approved by the Scientific Committee of the Department of Pharmacology and Toxicology, and by the Scientific Committee of the College of Pharmacy/ University of Baghdad.

\section{Lornoxicam and omega 3 fatty acids}

Lornoxicam vial of $8 \mathrm{mg} / 2 \mathrm{ml}$ was purchased from Ms Pharma (Jordan), and omega- 3 capsules of $1000 \mathrm{mg}$ pure fish-oil from (AMS) America Medic and science (USA).

\section{Experimental protocol}

Rats were randomly divided into four groups, seven animals each as follows:
Group I: Rats were intraperitoneally (IP) injected normal saline of $5 \mathrm{ml} / \mathrm{kg} /$ day dose for 14 days. This group served as a negative control.

Group II: Rats were IP injected with lornoxicam $0.7 \mathrm{mg} / \mathrm{kg} /$ day for 14 days ${ }^{(10)}$.

Group III: Rats were orally-administered omega-3 at a dose of $185 \mathrm{mg} / \mathrm{kg} /$ day by gavage tube for 14 days ${ }^{(11)}$.

Group IV: Rats were administered a combination of oral omega-3 (185mg/kg/day) with IP lornoxicam $(0.7 \mathrm{mg} / \mathrm{kg} / \mathrm{day})$ for 14 days.

Twenty-four hour after the end of treatment duration i.e. at day 15 the animals were euthanized by diethyl ether and then after cervical dislocation, liver of each animal was quickly excised and washed with ice-cold phosphate buffer saline (PBS) (pH 77.2) to descend excessive blood, then the liver tissue was weighed, and then cut down to a small pieces and $1 \mathrm{gm}$ of liver tissue was placed in tube containing $9 \mathrm{ml}$ of ice-cold PBS to prepare $10 \mathrm{ml}$ of tissue homogenate; the liver tissue then homogenized by the homogenizer after putting the tube containing tissue in beaker containing ice. The homogenate then centrifuged on $10000 \mathrm{rpm}$ for 15 minutes in a cold centrifuge and the supernatant then used to estimate ALT and AST enzymes levels; in addition to cytokines [tumor necrosis factor-alpha (TNF- $\alpha$ ), and interleukine-10 (IL-10)].

\section{Determination of alanine aminotransferase (ALT) activity level}

The principle of this assay uses enzymelinked immune-sorbent assay (ELISA) based on biotin double antibody sandwich technology. Standards and samples are pipetted into the wells that pre-coated with ALT monoclonal antibody and then incubated at $37^{\circ} \mathrm{C}$ for 60 minutes. After incubation, anti-ALT antibodies that labeled with biotin were added to unite with streptavidin-HRP to form an immune-complex. Un-bound enzymes then removed after incubation and washing; then substrate A and B were added. The solution turned blue and changed to yellow by the effect of acid. The shades of solution and the concentration of rat ALT were positively correlated ${ }^{(12)}$.

The assay range: 1U/L-200 U/L and the sensitivity: $0.52 \mathrm{U} / \mathrm{L}$.

\section{Determination of aspartate aminotransferase (AST) activity level}

The principle of this assay depends on enzyme-linked immune sorbent assay (ELISA) based on biotin double antibody sandwich technology. Standards and samples are pipetted into the wells that are pre-coated with AST-monoclonal antibody and then incubated at $37^{\circ} \mathrm{C}$ for 60 minutes. After incubation, AST-antibodies that labeled with biotin were added to unite with streptavidin-HRP, which forms the immune complex. Un-bound enzymes were removed after incubation and washed with washing buffer; then substrate A and B were 
added. The solution were turned to blue and changed to yellow with effect of acid. The shades of solution and the concentration of AST are positively correlated ${ }^{(13)}$.

The assay range: 1U/L-200U/L; and the sensitivity: $0.51 \mathrm{U} / \mathrm{L}$

Determination of tumor necrosis factor-alpha (TNF-alpha) level

The principle of this assay depends on enzyme-linked immune sorbent assay (ELISA) based on biotin double antibody sandwich technology. Standards and samples are pipetted into the wells that are pre-coated with TNF- $\alpha$ monoclonal antibody and then incubated at $37^{\circ} \mathrm{C}$ for 60 minutes. After incubation, TNF- $\alpha$-antibodies that labeled with biotin were added to unite with streptavidin-HRP, which forms the immune complex. Un-bound enzymes were removed after incubation and washed with washing buffer; then substrate A and B were added. The solution were turned to blue and changed to yellow with effect of acid. The shades of solution and the concentration of rat's TNF- $\alpha$ is positively correlated ${ }^{(14)}$.

Assay range: 5ng/L-1000ng/L. Sensitivity: $2.51 \mathrm{ng} / \mathrm{L}$

Determination of Interleukin-10 (IL-10) levels

The principle of this assay depends on enzyme-linked immune sorbent assay (ELISA) based on biotin double antibody sandwich technology. Standards and samples are pipetted into the wells that are pre-coated with IL-10-monoclonal antibody and then incubated at $37^{\circ} \mathrm{C}$ for 60 minutes. After incubation, IL-10-antibodies that labeled with biotin were added to unite with streptavidin-HRP, which forms the immune complex. Un-bound enzymes were removed after incubation and washed with washing buffer; then substrate A and B were added. The solution were turned to blue and changed to yellow with effect of acid. The shades of solution and the concentration of IL-10 are positively correlated ${ }^{(14)}$.

Assay range: $3 \mathrm{pg} / \mathrm{ml}-900 \mathrm{pg} / \mathrm{ml}$. Sensitivity: $1.51 \mathrm{pg} / \mathrm{ml}$.

\section{Statistical analysis}

Unpaired Student t-test was utilized to estimate the difference between two groups. The significance of differences among various groups was determined by One-way Analysis of Variance (ANOVA). Differences were statistically considered significant for $P$-value less than 0.05 and data were expressed as means \pm standard error of the mean (SEM).

\section{Results}

Table 1 showed that in group of rats intraperitoneally injected with therapeutic dose of lornoxicam $(0.7 \mathrm{mg} / \mathrm{kg}$ ) for 14 days (Group II) there were non-significant $(P>0.05)$ differences in both enzymes activity levels (ALT and AST) in liver tissue homogenate compared to the corresponding levels in negative control rats (Group I).

Table 1 showed that in group of rats intraperitoneally injected with therapeutic dose of lornoxicam $(0.7 \mathrm{mg} / \mathrm{kg}$ ) for 14 days (Group II) there were significant reduction $(P<0.05)$ in TNF- $\alpha$ level in liver tissue homogenate compared to negative control rats (Group I). In contrast, there was nonsignificant difference $(P>0.05)$ in IL-10 level in Group II rats' liver tissue homogenate treated with therapeutic dose of lornoxicam $(0.7 \mathrm{mg} / \mathrm{kg})$ compared to negative control rats (Group I).

Table1. Effect of therapeutic dose of lornoxicam on liver tissue enzymes (ALT and AST) and cytokines (TNF- $\alpha$, IL-10) levels in male rats $(N=7)$.

\begin{tabular}{|l|l|l|l|l||}
\hline Group & $\begin{array}{l}\text { Mean } \pm \text { SEM of } \\
\text { ALT } \\
\text { (IU/L) }\end{array}$ & $\begin{array}{l}\text { Mean } \pm \text { SEM of } \\
\text { AST } \\
\text { (IU/L) }\end{array}$ & $\begin{array}{l}\text { Mean } \pm \text { SEM } \\
\text { TNF-a } \\
\text { ng/L }\end{array}$ & $\begin{array}{l}\text { Mean } \pm \text { SEM of IL- } \\
\mathbf{1 0} \\
\text { pg/ml }\end{array}$ \\
\hline Group I & $20.568 \pm 1.94$ & $11.761 \pm 0.59$ & $281.17 \pm 18.3$ & $129.33 \pm 3.9$ \\
\hline Group II & $22.8991 \pm 2.242$ & $11.326 \pm 1.104$ & $237.5 \pm 17.6 *$ & $122.28 \pm 17.4$ \\
\hline
\end{tabular}

-Data presented as means \pm standard error of the mean (SEM).

- *: $P<0.05$ : Significant difference compared to negative control group.

-Group I: Negative control (NS); Group II: lornoxicam-treated rats $(0.7 \mathrm{mg} / \mathrm{kg})$.

- ALT: Alanine aminotransferase; AST: Aspartate aminotransferase; TNF- $\alpha$ : Tumour necrosis factor-alpha; IL10: Interleukin-10; - N: Number of animals

Table 2 showed that in group of rats orallyadministered omega $3(185 \mathrm{mg} / \mathrm{kg})$ alone for 14 days (Group III) there were non-significant difference $(P>0.05)$ in ALT, AST enzymes activity, and TNF$\alpha$ level in liver tissue homogenate compared to negative control rats (Group I). In contrast, a significant elevation $(P<0.05)$ in IL-10 level in Group III rats' liver tissue homogenate orallyadministered omega $3(185 \mathrm{mg} / \mathrm{kg})$ was shown compared to negative control rats (Group I). 
Table 2. Effects of omega-three ( $\omega$-3) fatty acids alone on the liver tissue liver tissue enzymes (ALT and AST) and cytokines (TNF- $\alpha$, IL-10) levels in male rats. $(\mathrm{N}=7)$.

\begin{tabular}{|l|l|l|l|l||}
\hline Group & $\begin{array}{l}\text { Mean } \pm \text { SEM } \\
\text { of ALT } \\
\text { (IU/L) }\end{array}$ & $\begin{array}{l}\text { Mean } \pm \text { SEM of } \\
\text { AST } \\
\text { (IU/L) }\end{array}$ & $\begin{array}{l}\text { Mean } \pm \text { SEM of TNF- } \alpha \\
\text { in liver tissue } \\
(\mathbf{n g} / \mathbf{L})\end{array}$ & $\begin{array}{l}\text { Mean } \pm \text { SEM of IL-10 } \\
\text { In liver tissue } \\
\text { (pg/ml) }\end{array}$ \\
\hline Group I & $20.568 \pm 1.94$ & $11.761 \pm 0.59$ & $281.17 \pm 18.3$ & $129.33 \pm 3.9$ \\
\hline Group III & $22.313 \pm 1.696$ & $12.927 \pm 1.763$ & $285.003 \pm 28.32$ & $148.2 \pm 16.77^{*}$ \\
\hline
\end{tabular}

-Data presented as means \pm standard error of the mean (SEM).

- *: $P<0.05$ : Significant difference compared to negative control group.

-Group I: Negative control (NS); Group III: Omega 3-treated rats (185mg/kg).

- ALT: Alanine aminotransferase; AST: Aspartate aminotransferase; TNF- $\alpha$ : Tumour necrosis factor-alpha; IL10: Interleukin-10; - N: Number of animals

Table 3 showed that male rats coadministered therapeutic dose of lornoxicam $(0.7 \mathrm{mg} / \mathrm{kg}) \quad$ intraperitoneally plus orallyadministered omega $3(185 \mathrm{mg} / \mathrm{kg})$ once daily for 14 days (Group IV) showed a significant elevation $(P<0.05)$ in both enzyme activity levels (ALT, and AST) in liver tissue homogenate each compared to the corresponding levels in male rats IP injected with therapeutic dose of lornoxicam $(0.7 \mathrm{mg} / \mathrm{kg})$ (Group II); similarly, there were significant elevation $(P<0.05)$ in both enzymes levels (ALT, and AST) in liver tissue homogenate in male rats coadministered therapeutic dose of lornoxicam $(0.7 \mathrm{mg} / \mathrm{kg})$ IP plus orally-administered omega 3 $(185 \mathrm{mg} / \mathrm{kg})$ once daily for 14 days (Group IV) compared to the corresponding levels in male rats orally-administered omega 3 alone (Group III).

Table 3 showed that male rats coadministered therapeutic dose of lornoxicam $(0.7 \mathrm{mg} / \mathrm{kg})$ IP plus orally-administered omega 3 $(185 \mathrm{mg} / \mathrm{kg})$ once daily for 14 days (Group IV) showed a non-significant difference $(P>0.05)$ in the level of TNF- $\alpha$ in liver tissue homogenate compared to the corresponding levels in male rats IP injected with therapeutic dose of lornoxicam $(0.7 \mathrm{mg} / \mathrm{kg}$ ) (Group II); but, there was a significant reduction $(P<0.05)$ in the level of TNF- $\alpha$ in liver tissue homogenate in male rats coadministered therapeutic dose of lornoxicam $(0.7 \mathrm{mg} / \mathrm{kg})$ IP plus orally-administered omega 3 $(185 \mathrm{mg} / \mathrm{kg})$ once daily for 14 days (Group IV) compared to the corresponding levels in male rats orally-administered omega 3 alone (Group III).

Additionally, table 3 showed that male rats coadministered therapeutic dose of lornoxicam $(0.7 \mathrm{mg} / \mathrm{kg})$ IP plus orally-administered omega 3 $(185 \mathrm{mg} / \mathrm{kg})$ once daily for 14 days (Group IV) showed a significant elevation $(P<0.05)$ in the level of IL-10 in liver tissue homogenate compared to the corresponding levels in male rats IP injected with therapeutic dose of lornoxicam $(0.7 \mathrm{mg} / \mathrm{kg}$ ) (Group II); in contrast, there was non-significant difference $(P>0.05)$ in the level of IL-10 in liver tissue homogenate in Group IV (rats co-administered therapeutic dose of lornoxicam $(0.7 \mathrm{mg} / \mathrm{kg})$ IP plus orally-administered omega $3(185 \mathrm{mg} / \mathrm{kg})$ once daily for 14 days compared to the corresponding levels in male rats orally-administered omega 3 alone (Group III).

Table 3. Effect of co-administration of therapeutic dose of lornoxicam and omega 3 on the liver tissue enzymes (ALT and AST) and cytokines (TNF- $\alpha$, IL-10) levels in male rats compared to omega 3 and lornoxicam-treated group. ( $\mathrm{N}=7)$.

\begin{tabular}{|l|l|l|l|l||}
\hline \hline Group & $\begin{array}{l}\text { Mean } \pm \text { SEM of AST } \\
\text { IU/L) }\end{array}$ & $\begin{array}{l}\text { Mean } \pm \text { SEM of AST } \\
\text { (IU/L) }\end{array}$ & $\begin{array}{l}\text { Mean } \pm \text { SEM of TNF- } \alpha \\
\text { ng/L }\end{array}$ & $\begin{array}{l}\text { Mean } \pm \text { SEM of IL-10 } \\
\text { pg/ml }\end{array}$ \\
\hline Group II & $22.8991 \pm 2.242 \mathrm{~A}$ & $11.326 \pm 1.104 \mathrm{~A}$ & $237.5 \pm 17.6 \mathrm{~A}$ & $122.28 \pm 17.4 \mathrm{~A}$ \\
\hline Group III & $22.313 \pm 1.696 \mathrm{~A}$ & $12.927 \pm 1.763 \mathrm{~A}$ & $285.003 \pm 28.32 \mathrm{~B}$ & $148.2 \pm 16.77 \mathrm{~B}$ \\
\hline Group IV & $19.913 \pm 1.487 \mathrm{~B}$ & $13.908 \pm 1.531 \mathrm{~A}$ & $241.8 \pm 15.2 \mathrm{~A}$ & $140.12 \pm 17.1 \mathrm{~B}$ \\
\hline
\end{tabular}

-Data presented as means \pm standard error of the mean (SEM).

- Values with non -identical capital letters (A, and B) are significantly different $(P<0.05)$.

-Group II: lornoxicam-treated $(0.114 \mathrm{mg} / \mathrm{kg})$; Group III: Omega 3-treated rats (185 mg/kg); Group IV: Omega

$3(185 \mathrm{mg} / \mathrm{kg})$ plus lornoxicam-treated $(0.7 \mathrm{mg} / \mathrm{kg})$.

- ALT: Alanine aminotransferase; AST: Aspartate aminotransferase; TNF- $\alpha$ : Tumour necrosis factor-alpha; IL-

10: Interleukin-10; - N: Number of animals. 


\section{Discussion}

Results obtained from this study showed that therapeutic dose of lornoxicam $(0.7 \mathrm{mg} / \mathrm{kg})$ intraperitoneally injected for 14 days (Group II) produced non-significant $(P>0.05)$ differences in both enzymes activity levels (ALT and AST) in liver tissue homogenate compared to the corresponding levels in negative control rats (Group I) as shown in table 1. This could be attributed to the antiinflammatory effects of such drug. Results obtained from the current study are inconsistent with those obtained by others ${ }^{(15)}$; moreover, in the present study, TNF- $\alpha$ levels in liver tissue homogenate were significantly reduced $(P<0.05)$ and non-significant $(P>0.05)$ in IL-10 level in liver tissue homogenate of Group II (rats treated with therapeutic dose of lornoxicam $(0.7 \mathrm{mg} / \mathrm{kg})$ compared to negative control rats (Group I); this may indicate that lornoxicam used alone, may have the ability to reduce the inflammatory response during the study period. Authors illustrated the adverse effects of other drugs and chemicals on rats liver (16) (17); but, no previous studies were reported in order to compare results of this study with others concerning the effect of lornoxicam used at therapeutic dose alone on rats' liver.

It has been reported that TNF- $\alpha$ is a proinflammatory cytokine involved in various biological processes including regulation of cell proliferation, differentiation, apoptosis and immune response; and as a cell signaling protein involved in systemic inflammation. It is principally produced by -activated macrophages-, many other cell types. The deregulatory production of TNF has been implicated in a variety of diseases and drug-use (11)(18).

Moreover, results showed in table 3 revealed that levels of enzymes ALT and AST in liver tissue homogenate were respectively, significantlyreduced $(P<0.05)$ (ALT) and non-significantly changed $(P>0.05)$ (AST) when omega-3 was coadministered with lornoxicam for 14 days compared to lornoxicam-treated rats. Furthermore, table 3 also showed that TNF- $\alpha$ levels in liver tissue homogenate were not significantly changed $(P>0.05)$ when omega-3 was co-administered with lornoxicam for 14 days compared to lornoxicam-treated rats, respectively; but, there were significant reduction $(P<0.05)$ in the level of TNF- $\alpha$ in liver tissue homogenate of Group IV rats (combination) compared to the corresponding levels in male rats orally-administered omega 3 alone (Group III) (Table 3). This may be due to synergistic effects of combination treatment.

Additionally, table 3 showed that male rats coadministered therapeutic dose of lornoxicam $(0.7 \mathrm{mg} / \mathrm{kg})$ intraperitoneally plus orallyadministered omega $3(185 \mathrm{mg} / \mathrm{kg})$ once daily for 14 days (Group VI) showed a significant elevation $(P<0.05)$ in the level of IL-10 in liver tissue homogenate compared to the corresponding levels in male rats injected with therapeutic dose of lornoxicam $(0.7 \mathrm{mg} / \mathrm{kg}$ ) (Group III); this elevation of IL-10 may be due to a compensatory manner to regulate inflammatory mediators.

Authors reported that IL-10 is an immunomodulatory cytokine that may regulate the immune response by inhibiting the proliferation of certain immune cells and promoting the proliferation of others; this in turn may reduce the production of inflammatory cytokines; and may promote the secretion of antibodies, which bind to specific foreign molecules, thereby inactivating those molecules and marking them for destruction by other immune cells ${ }^{(19)}$. Furthermore, authors mentioned omega 3 had minimal side effects, and even at high doses administration, it was elevating levels of hepatic enzymes and not exhibit liver injury ${ }^{(20)}$.

In conclusion, the current study is the first that highlight the effect of utilizing alone, lornoxicam, or omega 3 on rats' liver; and again, it is the first that investigates the effect of combination of omega 3 co-administered with lornoxicam on rat's liver; thus, we did not have a chance to compare results of this study with others. The present study proved that, omega-3 can reduce signs of inflammation through the reduction- of TNF-alpha level and elevation of IL-10 with a significant reduction in ALT enzyme activity level in rats' liver tissue homogenate.

\section{References}

1. Shah S, Mehta V. Controversies and advances in non-steroidal anti-inflammatory drug (NSAID) analgesia in chronic pain management. Postgrad Med J. 2012; 88(1036):73-8.

2. Sriuttha $P$, Sirichanchuen B, and Permsuwan U. Hepatotoxicity of Nonsteroidal AntiInflammatory Drugs: A Systematic Review of Randomized Controlled Trials. Int J Hepatol. 2018; 2018: 5253623.

3. Balfour JA, Fitton A, Barradell LB. Lornoxicam. A review of its pharmacology and therapeutic potential in the management of painful and inflammatory conditions. Drugs 1996; 51(4): 639-57.

4. Coskun E, Dincer E, Turan G, Ozgültekin A. Postoperative Analgesic Efficacy of Preemptive and Postoperative Lornoxicam or Tramadol in Lumbar Disc Surgery. Turk J Anaesthesiol Reanim. 2019; 60963.

5. Pohlmeyer-Esch G, Mehdi N, Clarke D, Radhofer-Welte S. Evaluation of chronic oral toxicity and carcinogenic potential of lornoxicam in rats. Food Chem Toxicol. 1997; 35(9): 909-22.

6. Swanson D, Block R, and Mousa SA. Omega-3 Fatty Acids EPA and DHA: Health Benefits Throughout Life. Adv Nutr. 2012; 3(1): 1-7. 
7. Ye J and Ghosh S. Omega-3 PUFA vs. NSAIDs for Preventing Cardiac Inflammation. Front Cardiovasc Med. 2018; 5: 146.

8. Park JM, Han YM, Jeong M, Kim EH, Ko WJ, et al. Omega-3 polyunsaturated fatty acids as an angelus custos to rescue patients from NSAIDinduced gastroduodenal damage. Journal of Gastroenterology. 2015; 50(6): 614-625.

9. Nicholas Moore, Charles Pollack, and Paul Butkerait. Adverse drug reactions and drugdrug interactions with over-the-counter NSAIDs. Ther Clin Risk Manag. 2015; 11: 1061-1075. Published online 2015 Jul 15. doi: 10.2147/TCRM.S79135.

10. Rabab R. El-zoghby and Mona F. Biochemical and histopathological changes of lornoxicam in Albino rats. Proc. of the 5th Animal Wealth Research Conf. in the Middle East and North Africa 2012: 254 - 271.

11. Alaa K. J. Al-Rikabi and Nada N Alshawi. Impacts of simultaneous administration of omega-3 fatty acids with amoxicillin/clavulanic acid on albino rats' liver and bile. IJPS. 2016; 41(2): 1-5.

12. Sasaki Y, Ohfuji S, Fukushima W, Tamori A, Enomoto M, Habu D, et al. Effect of caffeinecontaining beverage consumption on serum alanine aminotransferase levels in patients with chronic hepatitis $\mathrm{C}$ virus infection: a hospitalbased cohort study. PLoS One. 2013; 8(12): e83382.

13. Wilkie SE, Roper MJ, Smith GA, Warren MJ. Isolation, characterization and expression of a
cDNA clone encoding plastid aspartate aminotransferase from Arabidopsis thaliana. Plant Molecular Biology. 1995; 27(6): 12271233.

14. Hongbao, Ma; Shieh K, Lee SL. Study of ELISA Technique. Nature and Science. 2006; 4(2): 36-37.

15. Attyah AM, Ismail SH. Protective effect of ginger extract against cisplatin-induced hepatotoxicity and cardiotoxicity in rats. IJPS. 2012; 21(1): 1-7.

16. Kumar G, Sharmila BG, Vanitha PP et al. Hepatoprotective activity of Triantherma portulacastrum L. against paracetamol and thioacetamide intoxication in albino rats. $\mathrm{J}$ Ethnopharmacol. 2004; 92:37- 40.

17. Walsh $\mathrm{K}$ and Alexander G. Alcoholic liver disease. Postgrad Med J. 2000; 76 (895): 280-6.

18. Bobińska K, Gałecka E, Szemraj J, Gałecki P, Talarowska M. "Is there a link between TNF gene expression and cognitive deficits in depression?". Acta Biochim Pol. 2017; 64 (1): 65-73.

19. Manuela G. Neuman, Ph.D. CytokinesCentral Factors in Alcoholic Liver Disease. Alcohol Research and Health. 2003; 27 (4):309.

20. Harris WS, Ginsberg HN, Arunakul N, Shachter NS, Windsor SL, et al. Safety and efficacy of Omacor in severe hypertriglyceridemia. J Cardiovasc Risk 1997; 4(5-6): 385-91.

Baghdad Iraqi Journal Pharmaceutical Sciences by bijps is licensed under a Creative Commons Attribution 4.0 International License. Copyrights@ 2015 College of Pharmacy - University of Baghdad. 